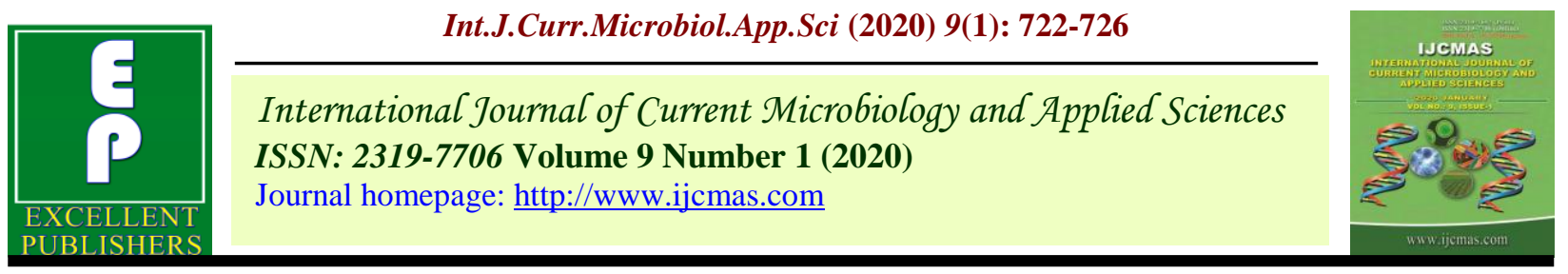

Original Research Article

https://doi.org/10.20546/ijcmas.2020.901.078

\title{
To Economize the Feed Cost of Broiler Japanese Quail (Coturnix coturnix japonica) by Feeding Fish Silage
}

\author{
A. Mohanty ${ }^{1 *}$, L. K. Babu ${ }^{1}$, B. Sahoo ${ }^{2}$ and S. M. Nanda ${ }^{3}$ \\ ${ }^{1}$ Department of Livestock Production and Management, College of Veterinary Science \& \\ Animal Husbandry, OUAT, Bhubaneswar-751003, India \\ ${ }^{2}$ ICAR-Central Institute for Women in Agriculture, Bhubaneswar, Odisha, India \\ ${ }^{3}$ Department of Veterinary \& Animal Husbandry Extension, College of Veterinary Science \& \\ Animal Husbandry, OUAT, Bhubaneswar-751003, India \\ *Corresponding author
}

Keywords

Fish silage,

Economization,

Broiler Japanese quail

\section{Article Info}

Accepted:

15 December 2019

Available Online:

20 January 2020

\section{A B S T R A C T}

The present day Indians prefer quail meat due to low cholesterol and fat content than that of other poultry meats. One hundred ninety two (192) 7 days old broiler quail chicks of either sex were taken for the study. The chicks were weighed and randomly distributed into four dietary treatments with four replicates in each group having twelve (12) chicks in each replicate. The dietary treatments were: $\mathrm{T}_{1}$ - control diet; $\mathrm{T}_{2}$ - diet containing $5 \%$ fish silage and $\mathrm{T}_{3}$-diet containing $10 \%$ fish silage and $\mathrm{T}_{4}$ - diet containing $15 \%$ fish silage. The cost of experimental diet per $\mathrm{kg}$ fed to the birds during the period of experiment was estimated to be Rs $29.11\left(\mathrm{~T}_{1}\right)$, 28.52( $\left.\mathrm{T}_{2}\right), 28.10\left(\mathrm{~T}_{3}\right)$ and $27.72\left(\mathrm{~T}_{4}\right)$. The cost of feed per $\mathrm{kg}$ of weight gain was the lowest in $\mathrm{T}_{2}$ (Rs.99.88) while it was highest in case of $\mathrm{T}_{3}$ (Rs 121.62). Therefore, it is concluded that AFS can be included at $5 \%$ level in the diet of broiler Japanese quails to economize the feed cost.

\section{Introduction}

Quail farming is in demand in the present days as quails are hardy, easy to handle and can accommodate to various agro climatic regions which again suits to the requirements of Indian farmers. The health conscious consumers of modern Indian societies also prefer quails as a source of lean meat having relatively low fat and cholesterol than that of other poultry meat. The low floor space requirement of quail encourages the small or marginal farmers for quail farming. According to Livestock census (2012) the quail population of India has shown a marked increase. The concept of fish silage first came from Sweden in the year 1930 followed by Denmark making the first commercial fish 
silage production in 1940 (FAO, 2016). Fish silage basically is a liquid product made from either whole fish or parts of fish that are liquefied by action of enzymes in the fish in the presence of an added acid. The enzymes breakdown the fish proteins into smaller soluble units and the acid help to speed up their activity while preventing bacterial spoilage (FAO, 2016). It can be prepared by ensiling the fish waste either by addition of organic and inorganic acids which is also known as acid treated or chemical silage or by addition of a carbon source and Lactobacilli bacteria for lactic acid fermentation also known as fermented or biological fish silage (Ramirez et al., 2013). The acid treated silage is considered to be better than that of the fermented one because of a lower cost of production involved. Taking both cost and quality, formic acid is the acid of choice for preparation of acid treated silage.

\section{Materials and Methods}

One hundred ninety two (192) 7day old broiler quail chicks of either sex, were taken for the study. The chicks were weighed and randomly distributed into four dietary treatments with four replicates in each group having twelve (12) chicks in each replicate. The experiment was carried out for a period of 4 weeks.

The dietary treatments were: $T_{1}$ - control diet; $\mathrm{T}_{2}$ - diet containing $5 \%$ fish silage and $\mathrm{T}_{3}$-diet containing $10 \%$ fish silage and $\mathrm{T}_{4}$ - diet containing $15 \%$ fish silage.

The chicks were fed with iso-caloric and isonitrogenous diet from $7^{\text {th }}$ to $35^{\text {th }}$ day of life. The chicks under treatment groups were provided with prescribed incorporation of fish silage from $7^{\text {th }}$ to $35^{\text {th }}$ day of life. During the period of study all the birds were given with a balanced diet having $2905 \mathrm{Kcal}$ of $\mathrm{ME} / \mathrm{Kg}$ of ration and $23.9 \%$ C.P. approximately. The ingredients and the nutrient composition are presented in Table 2 and 3.

The data pertaining to various parameters were subjected to statistical analysis under completely randomized design employing one way analysis of variance (Snedecor and Cochran, 1989). The means of different treatments were compared with Duncan's multiple range test (Duncan, 1955). Significance was considered at $\mathrm{p}<0.05$ level.

\section{Results and Discussion}

The cost of feed per kg live weight gain and the feed cost per bird are given in Table 4 . The cost of experimental diet per $\mathrm{kg}$ fed to the birds during the period of experiment was estimated to be Rs $29.11\left(\mathrm{~T}_{1}\right), 28.52\left(\mathrm{~T}_{2}\right)$, $28.10\left(\mathrm{~T}_{3}\right)$ and $27.72\left(\mathrm{~T}_{4}\right)$. The cost of feed per $\mathrm{kg}$ of weight gain was the lowest in $\mathrm{T}_{2}$ (Rs.99.88) while it was highest in case of $\mathrm{T}_{3}$ (Rs 121.62). However there was a difference of Rs 2.94 between $T_{1}$ and $T_{2}$ which shows that diet with $5 \%$ fish silage was more economical on weight gain basis.

The feed cost per kg live weight gain was lowest in $\mathrm{T}_{2}$ (5\% AFS) with a value of Rs 99.88, which could be attributed to the low cost of feed due to dietary incorporation of fish silage. This finding was in agreement with those of Boitai (2015) and Vedhanayakam et al., (1976) who reported lower cost of production due to dietary incorporation of AFS in broiler chicken. The cost of feed per $\mathrm{kg}$ weight gain in case of $\mathrm{T}_{3}$ was highest being higher than that of control, which could be due to comparatively higher FCR (4.33). Darsana et al., (2009) observed a reduction of Rs 0.50 per $\mathrm{kg}$ feed due to replacement of fish silage with fish meal in broiler diet causes without affecting overall performance. Dietary inclusion of AFS at 5\% level in broiler quail chicks reduced the feed cost by Rs 2.94 per kg live weight gain when 
compared to that of the control. Although a reduction in body weight gain $(12.12 \mathrm{~g})$ was observed in broiler quails due to dietary incorporation of 5\% AFS in the present study, an improvement in FCR amounting to saving of Rs 2.94 per $\mathrm{kg}$ live weight gain was observed.

Table.1 Design of the experiment

\begin{tabular}{|c|c|c|}
\hline Treatment no. & Treatment & No. of quail chicks \\
\hline Control group(T) & Control Diet & 48 \\
\hline $\mathbf{T}_{\mathbf{2}}$ & Diet with 5\% fish silage & 48 \\
\hline $\mathbf{T}_{\mathbf{3}}$ & Diet with 10\% Fish silage & 48 \\
\hline $\mathbf{T}_{\mathbf{4}}$ & Diet with 15\% Fish silage & 48 \\
\hline
\end{tabular}

Table.2 Formulation of fish silage with $0 \%, 5 \%, 10 \%$ and $15 \%$ Fish silage

\begin{tabular}{|l|l|c|c|c|c|}
\hline SI. & Ingredients (Parts/quintal) & $\begin{array}{c}\text { Control } \\
\text { No }\end{array}$ & $\begin{array}{c}\text { Diet with } \\
\mathbf{5 \%} \text { fish } \\
\text { silage }\end{array}$ & $\begin{array}{c}\text { Diet with } \\
\mathbf{1 0 \%} \\
\text { silage }\end{array}$ & $\begin{array}{c}\text { Diet with } \\
\text { 15\% fish } \\
\text { silage }\end{array}$ \\
\hline $\mathbf{1}$ & Maize & 58.1 & 53 & 51 & 47.9 \\
\hline $\mathbf{2}$ & Fish silage & - & 5 & 10 & 15 \\
\hline $\mathbf{3}$ & Deoiled rice bran & - & 3.05 & 3.2 & 3.9 \\
\hline $\mathbf{4}$ & Deoiled soya meal & 38.5 & 35.1 & 32.2 & 29.5 \\
\hline $\mathbf{5}$ & Choline chloride 50\% & 0.12 & 0.12 & 0.15 & 0.15 \\
\hline $\mathbf{6}$ & Salt & 0.2 & 0.25 & 0.25 & 0.25 \\
\hline $\mathbf{7}$ & Sodium bicarbonate & 0.2 & 0.2 & 0.2 & 0.2 \\
\hline $\mathbf{8}$ & Calcite powder $(\mathbf{C a}=\mathbf{3 4 \%})$ & 1.34 & 1.4 & 1.25 & 1.25 \\
\hline $\mathbf{9}$ & Dicalcium phosphate & 1.28 & 1.6 & 1.56 & 1.56 \\
\hline $\mathbf{1 0}$ & ABDK vitamin & 0.025 & 0.025 & 0.025 & 0.025 \\
\hline $\mathbf{1 1}$ & DL-Methionine & 0.12 & 0.13 & 0.13 & 0.14 \\
\hline $\mathbf{1 2}$ & B-complex & 0.03 & 0.025 & 0.025 & 0.025 \\
\hline $\mathbf{1 3}$ & Mineral mixture & 0.12 & 0.12 & 0.12 & 0.12 \\
\hline & TOTAL & $\mathbf{1 0 0 . 0 3 5}$ & $\mathbf{1 0 0 . 0 2}$ & $\mathbf{1 0 0 . 1 1}$ & $\mathbf{1 0 0 . 0 2}$ \\
\hline
\end{tabular}

Composition: Each $1 \mathrm{~kg}$ Trace min-CB contains Manganese: 90g, Zinc: 80g, Iron: 90g, Copper: 15g, Iodine: 2g, Selenium: $300 \mathrm{mg}$.

$* 5 \mathrm{~kg}$ fish silage (20 kg liquid silage), $10 \mathrm{~kg}$ fish silage (40 kg liquid silage), $15 \mathrm{~kg}$ fish silage (60kg fish silage) 
Table.3 Calculated values of different feeding treatments

\begin{tabular}{|c|c|c|c|c|}
\hline Calculated value & $\begin{array}{c}\text { Diet with 0\% } \\
\text { Fish silage }\end{array}$ & $\begin{array}{c}\text { Diet with 5\% } \\
\text { Fish silage }\end{array}$ & $\begin{array}{c}\text { Diet with 10\% } \\
\text { Fish silage }\end{array}$ & $\begin{array}{c}\text { Diet with 15\% } \\
\text { Fish silage }\end{array}$ \\
\hline ME (Kcal/Kg) & 2905 & 2925 & 2924 & 2940 \\
\hline CP\% & 23.9 & 23.83 & 23.85 & 23.69 \\
\hline CF\% & - & - & - & - \\
\hline Lysine(\%) & 1.26 & 1.28 & 1.29 & 0.51 \\
\hline Methionine(\%) & 0.35 & 0.5 & 0.51 & 0.92 \\
\hline Calcium(\%) & 0.9 & 0.9 & 0.91 & 0.44 \\
\hline Phosphorus(\%) & 0.42 & 0.43 & 0.44 & \\
\hline
\end{tabular}

Table.4 Economics of production

\begin{tabular}{|c|c|c|c|c|}
\hline Particulars & $\begin{array}{c}\mathbf{T}_{\mathbf{1}} \text { (Control diet } \\
\text { without fish } \\
\text { silage) }\end{array}$ & $\begin{array}{c}\mathbf{T}_{\mathbf{2}} \text { (Diet with } \\
\mathbf{5 \%} \text { fish silage) }\end{array}$ & $\begin{array}{c}\mathbf{T}_{\mathbf{3}} \text { (Diet with } \\
\mathbf{1 0 \%} \text { fish } \\
\text { silage) }\end{array}$ & $\begin{array}{c}\mathbf{T}_{\mathbf{4}} \text { (Diet with } \\
\text { 15\% fish } \\
\text { silage) }\end{array}$ \\
\hline $\begin{array}{c}\text { Cumulative body } \\
\text { weight gain (g) }\end{array}$ & 123.10 & 110.98 & 80.25 & 70.01 \\
\hline $\begin{array}{c}\text { Cumulative feed } \\
\text { consumption(g) }\end{array}$ & 434.19 & 391.97 & 347.35 & 288.66 \\
\hline $\begin{array}{c}\text { Cumulative FCR } \\
\text { Cost of feed/ bird } \\
\text { (During }\end{array}$ & 3.53 & 3.53 & 4.33 & 4.12 \\
\hline $\begin{array}{c}\text { Rs } 12.64 \\
\text { experimental period) }\end{array}$ & Rs 11.17 & Rs 9.76 & Rs 8.00 \\
\hline $\begin{array}{c}\text { Cost of feed / kg } \\
\text { weight gain }\end{array}$ & Rs.102.82 & Rs.99.88 & Rs. 121.62 & Rs. 114.31 \\
\hline
\end{tabular}

In conclusion, acid Treated Fish Silage can be included at 5\% level in the diet of broiler Japanese quails to economize the feed cost. This can help in economizing the cost of production for commercial quail farms and for the farmers at village level.

\section{References}

Boitai SS. 2015. Effect of feeding fish silage on the performance of broiler chickens, M.V.Sc. thesis submitted to
Orissa University of Agriculture and Technology, Bhubaneswar.

Darsana MG, Sreekumar KP and Jalaludeen A. 2009. Effect of feeding processed fish wastes on the growth and haematology of broilers, Indian Journal of Poultry Science 44(2): 213217.

Duncan DB. 1955. Multiple range and multiple F test. Biometrics, 11:1-42.

Ramírez JCR, Ibarra JI, Romero FA, Ulloa PR, Ulloa JA, Matsumoto KS, 
Cordoba BV and Manzano MAM. Snedcor GW and Cochran WG. 1989. 2013. Preparation of Biological Fish Silage and its Effect on the Performance and Meat Quality Characteristics of Quails (Coturnix coturnix japonica), Brazilian Archives of Biology and Technology, 56(6): 1002-1010 Statistical Methods. Oxford and IBH, Publishing company, New Delhi.

Vedhanayakam K, Jaganafhan $\mathrm{V}$ and Venkatakrishnan R. 1976. Use of fish silage in chick rations, Cheiron, 5: $122-125$.

\section{How to cite this article:}

Mohanty, A., L. K. Babu, B. Sahoo and Nanda, S. M. 2020. To Economize the Feed Cost of Broiler Japanese Quail (Coturnix coturnix japonica) by Feeding Fish Silage. Int.J.Curr.Microbiol.App.Sci. 9(01): 722-726. doi: https://doi.org/10.20546/ijcmas.2020.901.078 